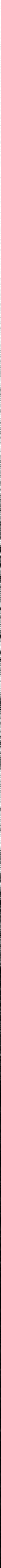


HISTORISK SAMFUND

FOR S $\varnothing N D E R J Y L L A N D$

holder

$\AA \mathrm{RSM} \varnothing \mathrm{DE}$

sondag den 27. maj kl. 14

i Løgumkloster Forsamlingshus.

Dagsorden:

1) Beretning.

2) Regnskab.

3) Sønderjysk Månedsskrift:

Beretning og regnskab.

4) Valg af styrelsesmedlemmer og revisorer. Efter tur afgår Werner Christiansen, Knud Fanø, Jens Holdt og Joh. Hvidtfeldt samt begge revisorer: S. Schoubye og C. H. Sehrt.

H. Neumann har ønsket at udtræde af styrelsen.

5) Eventuelt.

Efter kaffebordet taler arkitekt Elna Møller, Nationalmuseet, om »Den middelalderlige kirke som arbejdsplads med særligt henblik på Sønderjylland « (med lysbilleder).

Styrelsen.

\section{HALVBIND 1962}

Gdr. Ernst Christensen, Asserballe: Landbevæbningen på Als under Treårskrigen.

Arkivar Henning Heilesen, Åbenrå:

De sønderjyske gråbrødreklostres undergang.

Et blad af reformationens historie i Sønderjylland.

Pastor H. F. Petersen, Satrup:

De sønderjyske vajsenhuse.

Omslagsbilledet:

Grønnebæksbro i NфrTeskov pá Als.

Broen er formentligt bygget af hertug Hans $d$. Yngre.

Fot. Robert Huhle. 